\title{
International monetary policy with commodity buffer stocks
}

\author{
Leanne Ussher \\ Queens College, City University of New York, USA
}

This proposal argues in favor of commodity price stabilization via international commodity buffer stocks and the tying of these stocks to the creation of a new international reserve currency. Financing commodity buffer stocks through the issuance of an international reserve makes commodity price stabilization financially viable and offers a countercyclical issuance of international reserves to fight global deflation. Both measures address the volatility of commodity prices due to a lack of private sector storage and macroeconomic demand factors. This proposal urges the reader to look back to the global Keynesian policies of the 1940s, 1960s, and 1970s for inspiration in solving today's commodity price instability and secular stagnation.

Keywords: commodity buffer stocks, commodity reserve currency, resource security

JEL codes: $B 26, F 02, Q 02$

'Assuredly nothing can be more inefficient than the present system by which the price is always too high or too low and there are perpetual meaningless fluctuations in the plant and labor force employed.'

(Keynes 1974: 451).

\section{INTRODUCTION}

The above quote refers to primary commodity prices, and to Keynes's plea that almost any market intervention was better than none. Primary commodities account for more than one-fifth of global trade, and 65 percent of all developing countries derive more than 50 percent of their export income from commodities (UNCTAD 2011). Commodity price volatility for these countries endangers food security, raises balance-of-payments volatility, dampens producers' supply responses to price spikes, makes difficult calculations of long-run opportunity costs, compromises optimal investment paths at both government and private sector level, and harms economic growth (Cavalcanti et al. 2011).

Commodity prices are characterized by long periods of depressed prices, punctuated with high prices. The reasons for their price instability and persistence (long continuing movement away from the mean path) are many: the inelasticity of market supply and demand for both prices and incomes; the insufficiency of private storage to minimize stock-outs; autocorrelation in prices from speculative storage (Williams/Wright 1991); increase in volatility during low stocks and panics (Stigler/Prakash 2013); production lags and adaptive expectations (Kaldor 1934; Nerlove 1958); low investment due to risk aversion; volatility in the unit of account in which commodities are priced (Cashin/McDermott 2002); changes in international interest rates and liquidity

Received 11 September 2015, accepted 22 January 2016 
(Frankel 1986); world economic growth (Erten/Ocampo 2012); diversion of some grains into fuel products (Wright 2013); excess financial speculation and financialization of commodities (UNCTAD 2009); commodity-dependent exporting nations forced to increase production to compensate for falling prices (Maizels 1994); national subsidies and international dumping of surplus commodities; and the potential for even more extreme price movements in the future due to climate change.

Commodity markets are not just Pareto inefficient. As they are essential to economic security and progress for so much of the world's population, their pronounced volatility and market imperfections thrust issues of distribution and intervention onto the agenda. Stabilization of the terms of trade of commodity prices relative to manufactured exports is one area that has been hotly debated in the past and created a divide between countries that primarily export commodities versus manufactured goods.

Washing over distributional issues, mainstream economists who take a supply-side approach often argue that low commodity prices should translate into higher spending on net and therefore a support for world growth (for example, see Husain et al. 2015 on oil). However, empirically countries with diversified exports (less than 50 percent commodities) appear not to be affected by international commodity price volatility and higher commodity prices. However, volatility and lower commodity terms of trade do dramatically harm the growth of commodity exporters, with volatility being the worse of the two offenders (Cavalcanti et al. 2011). This suggests that stable and somewhat higher commodity prices are compatible with higher world growth.

At a national level, commodity price instability has been a major concern for policymakers since time immemorial, made famous by the Biblical story of Joseph and the granaries of Egypt. Despite the critics of buffer stock sustainability, governments that stabilize domestic food and fuel prices at a low cost to economic growth, and with participation by the poor or politically vocal, are typically rewarded with greater political stability, food security, and domestic welfare gains (Dawe/Timmer 2012; Magrini et al. 2014). Following the 2008 food crisis, many poorer nations are questioning the free market ideology that has increased their reliance on imports and exports of cash crops, making them more vulnerable in times of crisis. As a result, emergency stockpiling and price stabilization programs to promote self-sufficiency have become more popular. These national acts can help guard against supply shocks and be used to dampen local price volatility but they can be expensive. The subsidization of private storage may be a cheaper alternative than national storage programs (Williams/Wright 1991).

Another problem is that both importing and exporting countries that stabilize grain or oil prices internally will use the world markets to dispose of surpluses or meet deficits through imports. By and large, Asia, the US, and Europe have figured out how to do this domestically, but with large negative international spillovers. Africa does not have a viable strategy for stabilizing its domestic food prices, and the continent suffers even more from the instability in world markets transmitted from the Asian, European, and US approach to price stabilization, agricultural subsidies, taxes, and trade policies. Many of the national stabilization schemes, which create a wedge between domestic and external prices, have been discredited and described largely as inefficient (World Bank 2012) due to their negative spillovers. But what of international schemes that promote a uniform price?

Stabilization of international commodity prices, especially of grains, is also getting more attention since 2008. The problem with international commodity agreements has always been that those countries that would best benefit from commodity price stabilization are those that are least suited to maintaining buffer stocks. When prices decline and their incomes are reduced, producer cartels are the least able to spend money buying 
stocks and stabilize prices. In addition, there is limited incentive to reduce prices and sell from their stockpile when prices are high.

Prior to the 1980s, international commodity agreements and commodity buffer stocks were standard components of developing country demands for a 'New International Economic Order.' Initiatives that accompanied the stabilization of international commodity prices were the making of the International Monetary Fund special drawing rights (SDRs), the principal reserve asset in international payments, and increasing SDR issuance and its connection to the financial needs of developing countries (UNCTAD 2006). Such goals were laid out in 1942 by Keynes (1942 [1974]) in his original Bretton Woods plans, the failed 1948 Havana Charter to create an International Trade Organization (ITO), and the United Nations Conference on Trade and Development (UNCTAD) working papers that proposed to back SDRs with commodity buffer stocks (Hart et al. 1964; Kaldor 1972; Rweyemamu 1980).

Commodity buffer stock proposals and almost all research into them ended with the 1980s and the rise of the Washington Consensus. Beginning with Newbery/Stiglitz (1981) and later Williams/Wright (1991), there rose the dominance of a single 'doctrine' which showed that public interventions are unlikely to improve social welfare. Instead this new doctrine advocated increased liberalization of commodity markets and the use of riskhedging tools provided by futures markets. Their market-based doctrine was based on four specific assumptions: price instability stems exclusively from exogenous shocks; storers are risk-neutral; farmers are risk-neutral; and consumers are little affected as the product considered is a negligible proportion of their expenditure (see Galtier 2013 for a detailed critique).

At heart these theories ignored the macroeconomic aspects and coordination failures of international commodity markets that have resulted in a food crisis every 3 decades; balance-of-payment-constrained growth and commodity dependency; a 'commodity curse' on nations that should otherwise be considered blessed given their natural resources; the demise of the small farmer and indigeneous resource ownership to the benefit of trans-global profits; and a system where both public and private sectors in poor regions undervalue agricultural investment, leading to a bias towards urban domestic policies (Timmer 1995).

This paper advocates an old idea: international commodity buffer stocks financed through issuance of an international commodity reserve currency (CRC). Along with converting commodity stocks into liquid international reserve assets, this is a plan to create international countercyclical policies that can stimulate or constrain global economic growth. This paper will first highlight, in Section 2, the importance of ample world stocks to allow speculators to reduce price volatility. Very low stock-use ratios increase price volatility as speculation then becomes destabilizing. The problem with ample stocks is that they have a tendency to depress prices, reducing investment in commodities and leading to future price spikes. Section 3 summarizes the havoc real commodity prices undergo simply by being priced in US\$. Section 4 then outlines a solution to these problems an International Commodity Corporation (ICC) - and explains how it would operate to smooth the international business cycle. Section 5 gives a list of nine possible criticisms of an ICC, and Section 6 concludes.

\section{COMMODITY PRICE VOLATILITY AND STOCK-USE RATIOS}

When talking about global markets and commodity price volatility, it is important to take note of the actual size of world stocks, and the role that inventories play in smoothing or 


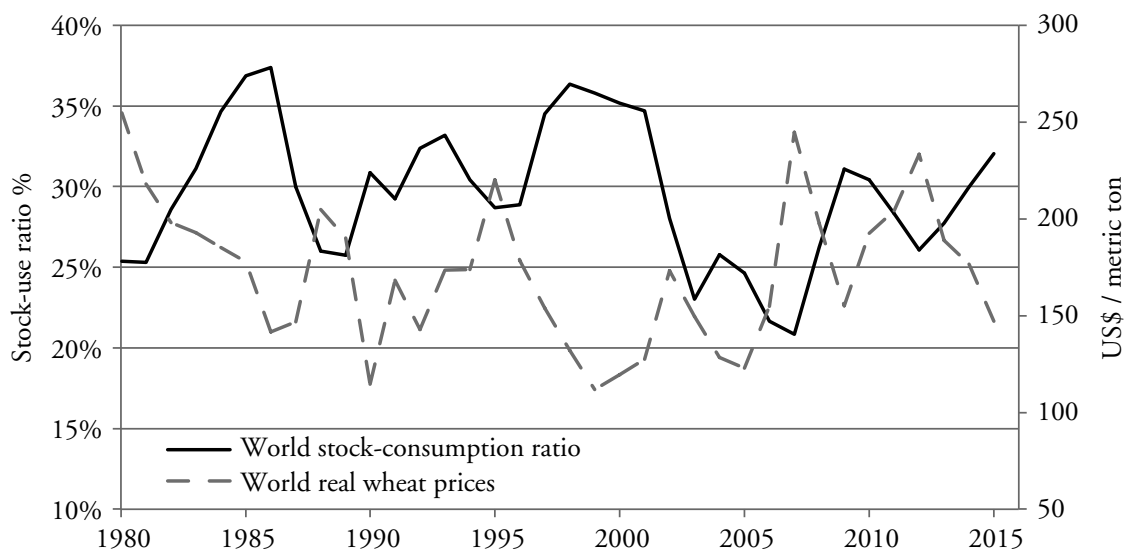

Source: End year production and stocks taken from table 4, and world prices from table 20, in the USDA World Year Book (Wheat Data, http://www.ers.usda.gov/data-products/wheat-data.aspx). End year real wheat prices, deflated by US producer price index (PPI) (all commodities) from the Labor Bureau of Statistics.

\section{Figure 1 Wheat stock-consumption ratio vs deflated wheat prices}

destabilizing prices. As an example, Figure 1 shows the strongly inverse relationship between wheat commodity prices and world-stock-to-use ratios. Under the standard speculative storage model for grains:

[T] he variance of price in the market is lower when storage is positive than when it is at its lower bound; storage stabilizes price and consumption. Storage reduces the frequency of high prices, and it reduces the frequency of low prices even more effectively. It moves the tails of the distribution toward the center, for both prices and consumption. (Bobenrieth et al. 2012: 13).

The empirical studies agree (Prakash 2013) that private storage by speculators is stabilizing when stocks are ample, smoothing prices and consumption. However, when stocks reach some lower bound and the risk of a stock-out rises, speculators - instead of selling when prices are rising - start buying.

While the data on private inventories are relatively scarce, it would appear that inventories were at historic lows from 2003 to 2008 and that during 2007 and 2008 private inventories were either not available or unwilling to stabilize commodity prices and inventories were growing just when they should have been decreasing (Gilbert 2011). As an example of this, I show the price and inventory cycle for wheat in Figure 1.

Why did stock-to-use inventories in grain and other commodities (for example, copper) get so low in the early part of the 2000s? According to the inventory theory, low interest rates reduce the cost of storage, and should promote higher private stores. But from 2000 to 2014, despite low interest rates, global grain stocks, normalized by consumption, averaged 12 percent lower than in the decades prior, and commodity price volatility in turn was higher (Kozacek 2014).

One cause for the decline in stocks was the disbanding of public buffer stocks that accumulated in the 1980s and 1990s as a side-product of farm income support subsidies 
in developed countries. But an even more important explanation was China. In 19811982 China had stock-to-use ratios for maize, rice, and wheat of 66 percent, 33 percent, and 27 percent, respectively. With its immense government resources and positive historical experience with an 'ever-normal granary,' China had accumulated stocks during the great decline of commodity prices from 1981 to 2002 (see Figure 2). ${ }^{1}$ By 1999/2000, China had stock-use ratios of 106 percent, 94 percent, and 73 percent in maize, rice, and wheat respectively, near all-time records for China in all three grains (Dawe 2009: 3). ${ }^{2}$ When Chinese growth picked up from 2000 on, and commodity prices started to rise, they 'rationally' chose to run down their stocks. ${ }^{3}$

By 2004 a number of commodities reached international 20-year-low stock-use levels and speculators started to adjust their long-term expectations for an era of higher prices based on strong long-term Chinese growth and the presence of low inventories. In this period, instead of selling at high prices and depleting stocks further, stocks began to rise, leading to the price spikes and then commodity hoarding of 2007-2008 (Gilbert 2011; Bobenrieth et al. 2012).

Thus private inventories smooth prices when shocks to supply and demand are thought to be temporary, which is generally when stocks are ample. If shocks are thought to be permanent or long-lasting then private holdings of inventories can exacerbate and destabilize prices (Gruber/Vigfusson 2012).

Stock-to-use ratios can be used to predict future price volatility (Bobenrieth et al. 2012). If ample stocks are carried all the time then the number of stock-outs is reduced and market sentiment is less prone to panics (Stigler/Prakash 2013).

During the 1980s and 1990s, the decades of high buffer stocks, inventories moved inversely to prices and thus consumption and prices were smoothed more than they would have been had the stocks not existed. However, it has been shown empirically that ample world inventories have the tendency to depress the level of commodity prices (Gilbert 2011). The declining prices over the 1980s and 1990s, which lowered investment in agriculture and minerals, have been blamed directly for the later commodity price spikes and market turmoil. The proposal here seeks to find a way of maintaining ample stocks but at the same time promoting higher equilibrium prices through higher world growth.

\section{COMMODITY PRICE LEVELS AND THE MONETARY REGIME}

The international monetary regime and movements in the currency in which tradable goods are priced have a significant impact on the level of commodity prices and their terms of trade with manufactured goods (see Figure 2). ${ }^{4}$ Commodity prices are inversely related to changes in the value of their unit of account. The rise and fall of international

1. We do not know the rationale for China's stock build-up, but do make the inference that it was an economically rational response to falling prices and their rising need for raw materials.

2. The average stock-to-use ratio for countries other than China in 1999/2000 were 14 percent, 22 percent, and 18 percent for maize, wheat, and rice respectively. In 1983 the Food and Agriculture Organization (FAO) recommendation was that stocks needed only to be around 17-18 percent for adequate price and consumption stability (Dawe 2009).

3. A similar situation can be seen for copper: http://www.riskelia.com/blog/2010/02/whycommodity-prices-rise-together-with-inventories/.

4. See Cashin/McDermott (2002) and Pfaffenzeller et al. (2007) for long-run time series analysis of commodity prices under different monetary regimes. 


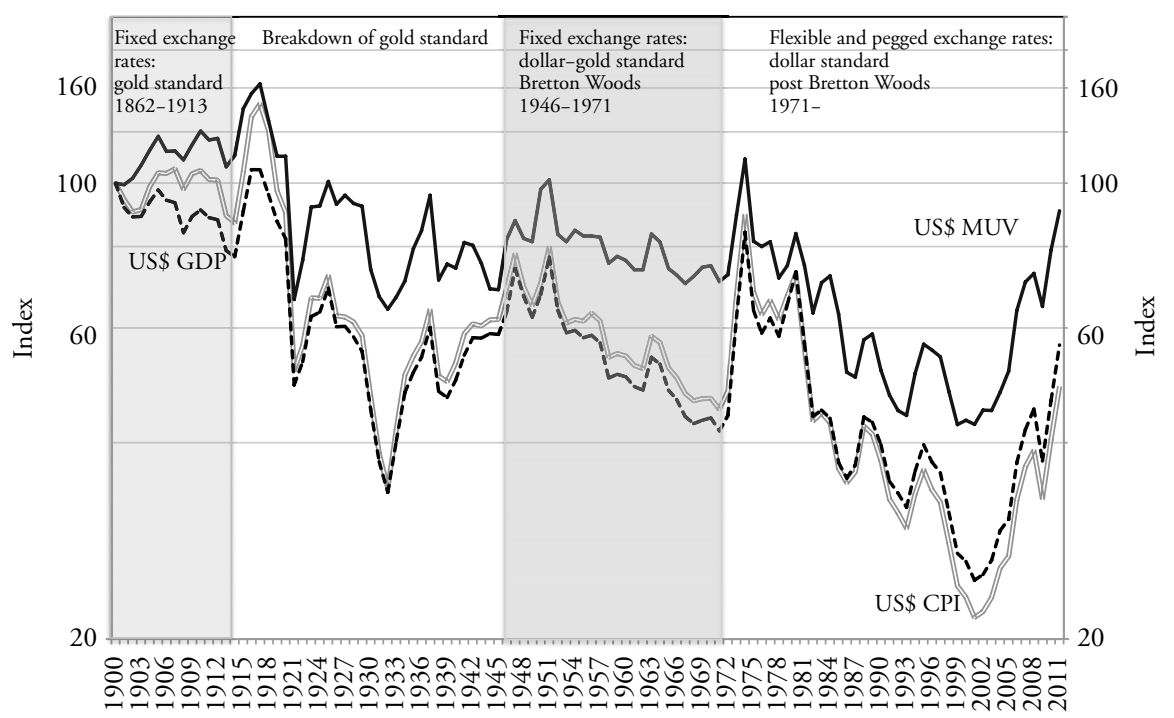

Notes: $1900=100, \log$ scale, US\$ commodity price deflated by either US\$ MUV, US\$ CPI or US\$ GDP.

Sources: Grilli and Yang non-fuel commodity price index (Grilli/Yang 1988), updated by author using Pfaffenzeller et al. (2007), http://www.stephan-pfaffenzeller.com/cpi.html; US\$ consumer price index (CPI) from Minneapolis Federal Reserve, http://www.minneapolisfed.com/community_education/ teacher/calc/hist1800.cfm; and US\$ GDP from Measuring Worth.com, http://www.measuringworth. com/usdgp. The non-fuel commodity index in US\$ is deflated by US CPI, US GDP, or the manufactured unit values (MUV) (the MUV is a composite index of prices for manufactured exports from the 15 major developed and emerging economies to low- and middle-income economies, valued in US dollars).

\section{Figure 2 Real non-fuel commodity price index}

commodity prices in the interwar period (see Figure 2's bottom-line US\$ CPI (Consumer Price Index)) was primarily a consequence of falling or rising gold valuations due to the dumping or hoarding of gold by central banks (Hawtrey 1923; Cassel 1936; Cashin/ McDermott 2002). ${ }^{5}$ We find the same account for the post-Bretton-Woods period of flexible exchange rates where commodity prices are inversely related to the US\$. Overall, since 1880 monetary regimes with flexible exchange rates have seen a far greater volatility in real commodity prices (Cuddington/Liang 2003).

There is a growing consensus that rather than a secular decline in the terms of trade between commodity prices relative to manufactured exports (the upper line in Figure 2) there are instead two downward structural breaks, one after World War I in 19201921 and the other at the beginning of the 1980s (Ocampo/Para 2003; Zanias 2005). The former period reflects the breakdown of the gold standard and a jump in real gold prices, and the latter period reflects the high real interest rates and strong dollar policy of the US in the 1980s and 1990s. This period was marked by balance-of-paymentconstrained growth (Thirwall 1979), falling commodity prices and revenues for less developed

5. The US\$ was fixed to gold up until 5 June 1933. 
countries, and a worsening of the international debt crisis (Maizels 1994). Poor commodity exporting nations were forced to increase commodity production to compensate for falling prices.

During the post Bretton Woods period, with the US\$ as the world's international reserve currency, export-led emerging markets, such as China, peg their currencies to the US\$, and devalue their currency to lower the international US\$ price of manufactured goods. If developing countries who sell commodities also follow these policies to promote their manufactured exports sector, then, due to the inelasticities of supply and demand in commodity markets compared to manufactured goods, this will lead to an even greater decline in world commodity prices.

Post-2002, the world saw lower US interest rates, a weaker dollar and in turn higher commodity prices, especially with the quantitative easing of the US Federal reserve after the global financial crisis of 2008. Flight from the US\$ led to speculators piling into commodities and raising their prices. During the 2000s, commodity prices returned to their average terms of trade seen during the Bretton Woods period. This period also witnessed significant improvement in less-developed country well-being and world economic growth. More recently, 2015 has seen weakening Chinese growth and a stronger US\$, both of which have reversed some of these commodity price gains.

\section{PROPOSAL: A COMMODITY-BACKED INTERNATIONAL CURRENCY}

Various economists from the twentieth century, such as Goudriaan (1932), Frank Graham (1941), Keynes (1942 [1974]), Hayek (1943), Benjamin Graham (1944), Kahn (see Rosselli 2012), Harrod (1963), Hart et al. (1964), Kaldor (1970), Hart (1976), Rweyemamu (1980), and more recently Lietaer (2004) and Ussher (2009), all advocate an international reserve currency (SDR) to be issued against the deposit of warehouse receipts for commodities constituting one or more commodity units (for a review of the main plans, see Ussher 2011). ${ }^{6}$ This real bills doctrine at the international level would offer new international reserve currency with a solid backing, redeemability, and a countercyclical supply. The goal would be for international trade to be ultimately priced and settled in CRC and for reserves to be held in CRC, rather than a key country currency like US\$. This event would reduce the concern over global imbalances since unlike the hoarding of US \$ assets, which create a US\$ debt counterpart, the counterpart of a CRC with 100 percent backing of commodities is just another asset. Thus hoarding CRC does not raise debt levels for other nations.

An international agency would be created, similar to a world central bank, called here the International Commodity Corporation (ICC). ${ }^{7}$ The ICC would be in charge of stabilizing commodity prices through commodity buffer stocks, paid for by a CRC which effectively represented the warehouse receipts of the commodities. Commodity price stabilization could target indices or individual commodities and policies could range from automatic with transparent stock holdings to discretionary and secretive.

Under the B. Graham (1944)-Hart et al. (1964) plan, the ICC would stabilize a broad-based index of storable standardized commodities that were internationally traded on futures exchanges. The commodity amounts in the index were weighted in relation to their significance in world trade or production. The index would exclude all monopoly

6. It has also been suggested, less convincingly, at a national level by Graham (1937) and Hall (1982), using just four commodities in the latter case.

7. B. Graham (1944) and Kaldor (1972) had the IMF be the ICC. 
products such as oil. The ICC would build up the buffer stock by purchasing individual commodities with its CRC at declared prices (see Hart et al. 1964 for details). While originally planned for central bank holding and settlement only, both central banks and the private sector could acquire and use CRCs. Countries would be encouraged to hold their reserves in $\mathrm{CRC}$, and to use CRC as the unit of account for all international trade and borrowing transactions. Once the buffer stock had reached its target size, perhaps 10 percent of world production, then the composite commodities and par value of the CRC would be set. Just as an example, the ICC could declare the CRC and its representative bundle of warehouse receipts to have terms of trade equal to $80 \mathrm{MUV}$, which was the approximate long-run average during the golden growth period of fixed exchange rates under the Bretton Woods system (see Figure 2). The declared value is the expected long-run trend for the commodity index. The ICC will be obliged to purchase the commodity unit (bundle of warehouse receipts) with CRC at say 2 percent below par value, and sell the commodity unit for CRC at 2 percent above par value. This corridor can be adjusted by the ICC and need not be symmetric. The ICC will actively make a market in CRC, thereby stabilizing its price around its target.

During a downturn, when the commodity basket is trading below the 2 percent discounted targeted floor, the ICC will be buying warehouse receipts in the specific ratios and building up its buffer stocks. The corridor should be wide enough to retain private speculation in the commodities, and could be as wide as 20 percent. The targeted terms of trade could be a moving average on the past 10 years. The buffer stocks are audited to give faith in the CRC. The basket weights, the targeted terms of trade, and the corridor are all adjustable, but this should be done rarely such that the operation is primarily automatic, non-discretionary and predictable. Like gold, there may be a small cost (negative interest charge) paid for holding CRC imposed by the ICC to go towards storage and spoilage costs. While a small fiduciary amount of CRC may be issued, in general most of the CRC would be fully backed by the basket of commodities. If commodities are in short supply then futures contracts can replace physical commodities.

As trade is increasingly priced in CRC, commodities will avoid the big swings in their aggregated terms of trade that we have seen under a floating US\$. The basket of homogeneous and internationally traded commodities could be 'greened' by including carbon permits (Lietaer 2004) or requiring a percentage of environmentally friendly approved commodities, over their current world trade proportions.

To keep the index within the allotted range, the ICC runs 'open market operations' by buying or selling the fixed basket of commodities in exchange for CRC. The ICC can buy up large stocks of commodities in exchange for CRCs without requiring a significant diversion of real resources from the ICC member countries to finance the stock accumulation. When the commodity index is below the floor in MUV, then the ICC buys and stores commodities and supplies CRC. The opposite occurs when the commodity index is above the selected MUV index.

The ICC proposal would create an international network of local storage areas at commodity exchanges, ports, and even on farm silos. The ICC would promote trade corridors, connecting regions and countries and the law of one price. Regular and independent audits would need to occur, facilitated by commodity bank cooperatives or commodity exchanges that could be subsidiaries of the ICC. Price stabilization would be based on long-run averages, discerned by technocrats and experts in charge of running the buffer stock. The commodity target would be pre-announced, adjustable, but modified rarely. The ICC would buy commodities when prices fall below a pre-stated floor and sell when prices rise above a pre-stated ceiling. ${ }^{8}$

8. An alternative is to have no announced floor and ceiling, but just have an experienced technocrat act as a market maker at the ICC (Kahn, cited in Rosselli 2012). 
A 2009 World Bank report (World Bank 2009) estimated that an international stockpile to stabilize international grain prices during the 2008 food crisis would have required 10 percent of global production, worth roughly US\$66 billion, and costing US\$4-6 billion to maintain (US\$1.4 billion in storage costs and US\$3-5 billion of spoilage costs based on losses in high-income countries). To put this into perspective, total losses to all consumers from rising food prices in 2007 were estimated at US\$270 billion. Given that people, producers and consumers, value stability over instability, and that food spikes have large welfare losses, US\$6 billion seems like a small expense.

Another example of open market operations for policy purposes is the large issuance of monetary reserves that occurred in the United States and Europe following the 2008 financial crisis. From 2008 until 2015 the Federal Reserve bought US\$3 trillion worth of financial assets, which they still have on their books. These assets will be unwound when the time warrants, and in the process they have reduced the risk of deflation, recapitalized the banks, and helped the economy by injecting liquidity into the system.

An ICC, acting as an international central bank with a single mandate - to stabilize a commodity index - that stood ready to buy commodities during a period of low prices (and low world demand), would inject reserves and liquidity into the system with direct payments to grain storers and producers. This would alleviate balance-of-payments-constrained countries that are dependent on commodity exports (roughly two-thirds of all developing countries). In turn, this would stimulate their demand for exports from manufacturing countries and accelerate world demand. The ICC would reduce the supply of international reserves when selling the index during commodity price spikes, typically during robust world demand or periods of excess private credit.

\section{CRITICISMS OF AN INTERNATIONAL COMMODITY CORPORATION (ICC)}

There are a number of objections that have been levied against buffer stock schemes (Wright/Prakash 2013) and more pointedly against the creation of a CRC (Friedman 1951; Grubel 1965). I mention some of these below:

1. An ICC would encourage production of mono-culture crops.

2. Higher commodity prices are bad for the urban and rural poor, who are net consumers of commodities.

3. An ICC reinforces the old colonial system where developing countries specialize in raw materials while industrialization occurs in the developed countries that produce manufactured goods with higher returns.

4. An ICC would distort commodity prices and ultimately create a surplus of commodities that would later have to be destroyed.

5. An exorbitant amount of commodities would need to be stored to stop speculators from betting against and breaking the 'bank,' during rising commodity prices.

6. The cost of storage is expensive and needs to be financed through taxes on countries.

7. Stabilizing an index can destabilize individual prices.

8. Capital flows are large and dominate trade flows, making the small amount of CRC issuance useless in international countercyclical monetary policy.

9. Garnering international agreement for an ICC and CRC would be impossible, hence this proposal is a utopian dream not worth investigation.

These 9 criticisms are not exhaustive, nor are the answers which follow complete, but it is hoped that this critique can stimulate future research focused on optimizing the ICC 
protocol to maximize welfare gains and create a viable international countercyclical policy tool.

\section{An ICC would encourage production of mono-culture crops}

This criticism is correct in that the point of the ICC is to stabilize and thereby promote investment and trade in goods priced in international markets. Producers will prefer to grow a crop that is included in the basket rather than outside the basket, to the extent that the market for in-basket commodities is more liquid. However, as many commodities have substitutes, even out-of-basket products will have their prices stabilized relative to the in-basket products by the market.

It is not obvious that an ICC would promote mono-culture agricultural commodities any more than the current status quo. Since the ICC stabilizes an index, excess production in individual commodities will result in a price decline in accordance with market dynamics. If the basket is broadly based, other commodities can be included in the basket to promote diversity and social welfare, greater than their share in current world trade, for example sustainably produced soybeans, clean coal, or carbon permits. Local policies to promote diversity through subsidies are not in conflict with an ICC.

\section{Higher commodity prices are bad for the urban and rural poor, who are net consumers of commodities}

High and stable commodity prices in Ethiopia and Zambia from national buffer stock programs have been shown by Bellemare et al. (2013) to be regressive - wealthy farmers are supported over poor consumers. However, the ultimate goal for the ICC is to ensure that cheap marginal producers get to sell their commodities at a stable competitive return. This may benefit producers initially over consumers, if prices are higher, but in the long run it benefits both, as prices are more predictable. Since 65 percent of developing countries derive more than half of their export income from commodities, stabilizing this income will raise their willingness to investment in these industries and their value added products. Local governments can still offer infant urban industry supports or food subsidies. But, importantly, with an ICC the less developed country's government will reap the benefits but not bear the burden of the buffer stock.

\section{An ICC reinforces the old colonial system where developing countries specialize in raw materials while industrialization occurs in the developed countries that produce manufactured goods with higher returns.}

The goal of an ICC is to help developing countries transition from commodity export dependence to the export of both commodities and manufactured goods. A shrinking resource sector through overall economic growth. Many development economists have argued that agriculture is critical to the early stages of development (World Bank 2007). Stable commodity prices allow risk-averse and small farmers the ability to invest and specialize, increasing farm yields. Progress in agriculture provides a foundation for capital and demand in other sectors, releasing workers for urban migration (Kaldor 1967; Timmer 2009). The commodity export surplus will raise foreign exchange and help finance domestic manufacturing and urban jobs - which undoubtedly becomes 
the most dynamic sector for growth. Commodity-led growth is followed by export-led growth of manufactured goods. With stable prices countries can avoid the commodity curse, which is due not to rich natural endowments, but to extreme price volatility.

\section{An ICC would distort commodity prices and ultimately create a surplus of commodities that would later have to be destroyed}

The goal of the ICC is to stabilize an index of commodity prices towards its long-run trend. While some individual commodities are thought to be non-stationary, the broad commodity index is thought to be stationary and thus predictable, although with two structural breaks (Zanias 2005). As the ICC stabilizes an index only, individual commodity prices can move with market supply and demand.

Index targets will be determined by independent technocrats, not producer cartels. Excessively high stock-use ratios across individual commodities would be signals for readjustment of the weights, and if across a majority of commodities then an indication of too high a floor price.

Despite the goal of not having buffer stocks as a growing share of world trade, it is important that the size of the buffer stock should be large and expansionary (or contractionary) when needed, to avoid stock-outs, and for the ICC to have a large stimulus impact when commodity prices are pushing outside the range.

Between the floor and ceiling prices, private storage should still take place in accordance with the inventory cycle (Williams/Wright 1991), as shown in Figure 1 for wheat. Some 'crowding out' of private stores means the lowering of transaction costs for the private sector and is seen as beneficial. If the ICC succeeds in keeping market expectations for long-term prices within the corridor then private storage and speculation should be stabilizing.

There is a long history behind the proposals by Keynes (1942 [1974]), B. Graham (1944), and Kaldor (1972), that specifically oppose the destruction of commodities. Large stocks of commodities should be considered an international treasure rather than a burden. It is illogical, given the degree of impoverishment in regions of the world, and now with the uncertainties created by global warming, that stockpiles of commodities, essential to economic growth, can be considered in excess. A distribution from these stockpiles for aid purposes can always occur as part of a fiduciary issue.

\section{An exorbitant amount of commodities would need to be stored to stop speculators from betting against and breaking the 'bank,' during rising commodity prices}

As commodity prices rise, the ICC will be putting downward pressure not only through releasing commodities but also by reducing the amount of CRC available. As individual commodity prices can fluctuate widely when offset by other commodity prices in the basket, it is unlikely that a stock-out will occur. The standard critique of buffer stocks being open to speculative attack when prices are rising (Townsend 1977; Salant 1983) is complicated when an index is stabilized.

The ICC needs to have a 'large enough' stock of commodities and the ceiling price be pegged 'high enough,' so the corridor will stabilize a stationary price trend most of the time, when the market's long-term price expectations are within the corridor. The ICC can always adjust its rule or even halt its activity, allowing a short-term price spike in the index above the ceiling target, while still meeting food security needs and minimizing the desire by individual countries to place restrictions on their exports or imports. 
For individual commodity price stabilization, avoiding a speculative attack was one reason why Kahn proposed buffer stocks that were not transparent and had secretive targets and operations (see Rosselli 2012).

A large buffer stock is seen as an advantage by an ICC that simultaneously issues a reserve currency, and operates countercyclically. By shrinking the ICC commodity inventories during periods of strong economic growth, the supply of international CRC will also shrink. The tightening of liquidity will constrain global trade and help stabilize or rather depress the commodity index back to its long-run range. Clearly the CRC trade multiplier is crucial to the ICC being able to operate countercyclical policy that moderates the size of the buffer stock.

\section{The cost of storage is expensive and needs to be financed through taxes on member countries}

The costs of storage, which are the running costs and spoilage, are considered low relative to the gains of international macro policy. The ICC would contract out the storage to commodity exchanges and warehouses, in selling or buying nations that may value storage for reasons of supply security. Storage costs could be paid for by nations that chose to store; by profits from the ICC buying the basket low and selling high; by the sale of spot for future contracts at a lower price during periods of temporary shortage in individual commodities; or finally by assessed contributions against member nations. Alternatively, the ICC could also issue a growing fiduciary amount of CRC if there was a liquidity preference for CRC, or widen the spread of the corridor to increase profits and lower storage levels.

\section{Stabilizing an index does not stabilize individual prices}

Under the stabilization of an index, relative prices of individual commodities are flexible according to supply and demand, however stabilization of the index requires that one or more prices rise while others go down. For example, if world wheat is short, but the global economy is deflationary, then the ICC will be buying warehouse receipts, and removing wheat stores from the market. Even if the ICC were to replace physical wheat with futures, and rolling these over, there would still be a greater upward pressure on spot wheat prices, especially if private stock-use ratios in wheat were falling. If wheat price jumps were very dramatic then the ICC board could consider removing wheat from the basket, however in general these additional price swings are possible. Such price swings are a natural hedged for producers who receive an even higher price for their smaller crop. This instability is a cost which is possibly countered by the higher aggregate equilibrium growth path.

If prices are positively correlated, then stabilization of the index may mean that individual prices are also stabilized on average. However, much more research is required on this issue, with consideration to cross elasticities and substitutions. It was due to these complications that Keynes and Kahn both preferred individual commodity buffer stocks over an index, despite their obvious drawbacks of limiting market supply and demand.

\section{Capital flows dominate trade flows, making the CRC useless in international countercyclical monetary policy}

It is true that short-term financial flows of credit currently far outweigh the proposed CRC issuance. But if exchange rates were eventually voluntarily fixed under a CRC there would be less reason for speculative short-term capital flows. 
Outside of this, 7 out of 10 of the world's poor are located in rural areas. Countries depending on commodities for at least 60 percent of their export earnings represented 94 of the 156 developing countries in 2009 . Higher commodity prices since 2000 have undoubtedly improved the potential economic growth of these countries by raising their foreign exchange, lifting balance-of-payment constraints and supporting investment in commodity sectors. These real side-benefits increase productivity in commodity production, facilitate rural to urban migration, and offer a steady transition to export-led growth in manufactured goods, reducing to some extent the reliance on foreign direct investment. If countries chose to fix their exchange rates to a CRC, then the removal of exchange fluctuations would reduce the amount of hot money flows in the financial system.

\section{Garnering international agreement for an ICC and CRC would be impossible, hence this proposal is a utopian dream not worth investigation}

The creation of a new CRC does not need international agreement. In theory a private company can create this currency (Lietaer 2004). As the CRC has a sound backing, it also doesn't need mutual trust or a liquid market to get it started.

\section{CONCLUSION}

Market prices for raw materials regularly lose their efficiency properties, and normative trade theories that demonize any intervention to stabilize food prices have lost their saliency. This paper argues for a return to the traditional solution to resource and food security: the consideration of commodity buffer stocks. This taboo topic has not seen the amount of research it deserves. A higher stock-to-use ratio can lower commodity price volatility. Speculative private inventories are not typically big enough by themselves and are prone to panics of stock-out, whether real or not. When world stocks are big enough they tend to put downward pressure on commodity prices which stifles the economic progress of the least developed nations, and their contribution to world aggregate demand. While public buffer stocks can supplement private aversion to holding stocks they cannot be created just for the critical periods when private storage fails. Long-run national commodity buffer stocks are expensive and ineffective without international coordination.

The creation of an international monetary authority to specifically stabilize commodity prices through buffer stocks can offer 'free' financing to the agency. Commodity warehouse receipts can back the issuance of a new international reserve currency. This is an international real bills approach that offers a countercyclical supply of new international reserve assets to the global community since commodities are positively correlated with economic growth. The creation of a new international currency offers commoditydependent exporting countries a stable minimum income, and makes commodities a liquid asset. If adopted as the benchmark for pricing all international goods, this new currency and agency can replace the US\$ as the world's international reserve, and offers the world a policy tool to reduce global imbalances, stabilize the terms of trade for commodity-dependent developing countries, and moderate global secular stagnation and inflation. 


\section{REFERENCES}

Bellemare, M.F., Barrett, C.B., Just, D.R. (2013): The welfare impacts of commodity price volatility: evidence from rural Ethiopia, in: American Journal of Agricultural Economics, 95(4), 877-899.

Bobenrieth, E., Wright, B.D., Zeng, D. (2012): Stocks-to-use ratios as indicators of vulnerability to spikes in global cereal markets, URL: http://www.amis-outlook.org/fileadmin/user_upload/amis/ docs/reports/AMIS_IG_12_4_Stock_to_use.pdf.

Cashin, P., McDermott, C.J. (2002): The long-run behavior of commodity prices: small trends and big variability, IMF Staff Papers, 49(2), 175-199.

Cassel, G. (1936): The Downfall of the Gold Standard, Oxford: The Clarendon Press.

Cavalcanti, T., Mohaddes, K., Raissi, M. (2011): Commodity price volatility and the sources of growth, IMF Working paper 12/12, January.

Cuddington, J., Liang, H. (2003): Commodity price volatility across exchange rate regimes, IMF Discussion Paper.

Dawe, D. (2009): The unimportance of 'low' world grain stocks for recent world price increases, ESA Working Paper No 09-01, February.

Dawe, D., Timmer, C.P. (2012): Why stable food prices are a good thing: lessons from stabilizing rice prices in Asia, in: Global Food Security, 1(2), 127-133.

Erten, B., Ocampo, J.A. (2012): Super-cycles of commodity prices since the mid-nineteenth century, DESA Working Paper No 110, February.

Frankel, J. (1986): Expectations and commodity price dynamics: the overshooting model, in: American Journal of Agricultural Economics, 68(2), 344-348.

Friedman, M. (1951): Commodity-reserve currency, in: Journal of Political Economy, 59(3), 203-232.

Galtier, F. (2013): Managing food price instability: critical assessment of the dominant doctrine, in: Global Food Security, 2(2013), 72-81.

Gilbert, C. (2011): International agreements for commodity price stabilisation: an assessment, in: OECD Food, Agriculture and Fisheries Papers, 53, URL: http://dx.doi.org/10.1787/ $5 \mathrm{~kg} 0 \mathrm{ps} 7 \mathrm{~d}$ s0jl-en.

Goudriaan, J. (1932): How to Stop Deflation, London: The Search Publishing.

Graham, B. (1937): Storage and Stability: A Modern Ever Normal Granary, New York and London: McGraw-Hill.

Graham, B. (1944): World Commodities and World Currency, New York: McGraw-Hill.

Graham, F.D. (1941): Transition to a commodity reserve currency, in: American Economic Review, 31, 520-525.

Grilli, E., Yang, M.C. (1988): Primary commodity prices, manufactured goods prices and the terms of trade in developing countries: what the long run shows, in: World Bank Economic Review, 2, $1-47$.

Grubel, H.G. (1965): The case against an international commodity reserve currency, Oxford Economic Papers, 17(1), 130-135.

Gruber, J.W., Vigfusson, R.J. (2012): Interest rates and the volatility and correlation of commodity prices, International Finance Discussion Papers, 1065, Board of Federal Reserve.

Hall, R.E. (1982): Explorations in the Gold standard and related policies for stabilizing the dollar, in: Hall, R.E. (ed.), Inflation: Causes and Effects, Chicago: University of Chicago Press, 111-122.

Harrod, R. (1963): Liquidity, in: Grubel, H.G. (ed.), World Monetary Reform, Redwood City, CA: Stanford University Press, 203-226.

Hart, A.G. (1976): The case as of 1976 for international commodity-reserve currency, in: Weltwirtschaftliches Archiv, 112(1), 1-32.

Hart, A.G., Kaldor, N., Tinbergen, J. (1964): The Case for an International Commodity Reserve Currency, Geneva: UNCTAD. (Reprinted in Kaldor, N., 1964, Essays on Economic Policy II: Vol. IV of Collected Economic Essays of Nicholas Kaldor, 1980 edition, New York: Holmes and Meier.)

Hawtrey, R.G. (1923): Monetary Reconstruction, London: Longmans, Green and Co., URL: https:// archive.org/stream/monetaryreconstr00hawtuoft\#page/142/mode/2up.

Hayek, F.A. (1943): A commodity reserve currency, The Economic Journal, 53(210), 176-184. 
Husain M.A., Arezki, R., Breuer, P., Haksar, V., Helbling, T., Medas, P., Sommer, M., and an IMF Staff Team (2015): Global implications of lower oil prices, IMF Discussion Paper, SDN 15/15, URL: https://www.imf.org/external/pubs/ft/sdn/2015/sdn1515.pdf.

Kaldor, N. (1934): A classificatory note on the determination of equilibrium, in: Review of Economic Studies, 1(2), 122-136.

Kaldor, N. (1967): Strategic Factors in Economic Development, New York: New York State School of Industrial and Labor Relations, Cornell University.

Kaldor, N. (1972): Money and gold, in: Acta Oeconomica, 9(2), 199-203.

Keynes, J.M. (1942 [1974]): The international control of raw materials, in: Journal of International Economics, 4, 299-315.

Kozacek, C. (2014): World food supplies recover from drought and reach low food stocks, high food prices, URL: http://www.circleofblue.org/waternews/2014/world/world-food-supplies-recoverdroughts-reach-15-year-high/.

Lietaer, B. (2004): The Terra TRCTM White Paper, Access Foundation, URL: http://www.terratrc. org/whitepapers.html.

Magrini, E., Nenci, S., Salvatici, L. (2014): Agricultural trade policies and food security: is there a causal relationship? Foodsecure working paper no 25, 1-37, September, URL: http://www3.lei. wur.nl/FoodSecurePublications/25_Salvatici_et_al_Agtrade-policies-FNS.pdf.

Maizels, A. (1994): The continuing commodity crisis of developing countries, in: World Development, 22(11), 1685-1695.

McKeon, N. (2011): Global governance for world food security: a scorecard four years after the eruption of the 'food crisis,' Berlin: Heinrich-Böll-Stiftung, URL: https://www.boell.de/sites/ default/files/Global-Governance-for-World-Food-Security.pdf.

Nerlove, Marc (1958): Adaptive expectations and cobweb phenomena, in: Quarterly Journal of Economics, 72(2), 227-240, doi:10.2307/1880597.

Newbery, D.M.G., Stiglitz, J.E. (1981): The Theory of Commodity Price Stabilization: A Study in the Economics of Risk, Oxford: Clarendon.

Ocampo, J., Para, M.A. (2003): The terms of trade for commodities in the twentieth century, in: CEPAL Review, 79, 7-35.

Pfaffenzeller, S., Newbold, P., Rayner, A. (2007): A short note on updating the Grilli and Yang commodity price index, in: World Bank Economic Review, 21(1), 1-13, doi:10.1093/wber/ lhlo13.

Prakash, A. (ed.) (2013): Safeguarding Food Security in Volatile Global Markets, URL: http://www. fao.org/docrep/013/i2107e/i2107e.pdf.

Prakash, A., Gilbert, C. (2013): Rising vulnerability in the global food system, beyond market fundamentals, in: Prakash, A. (ed.), Safeguarding Food Security in Volatile Global Markets, 45-66, URL: http://www.fao.org/docrep/013/i2107e/i2107e.pdf.

Rosselli, A. (2012): Richard Kahn and the stabilization of commodity prices, in: Marcuzzo, M.C. (ed.), Speculation and Regulation in Commodity Markets: The Keynesian Approach in Theory and Practice, Rome: Sapienza University of Rome, 207-224, URL: http://mpra.ub.unimuenchen.de/44131/ MPRA Paper No 44131.

Rweyemamu, J.F. (1980): Restructuring the international monetary system, in: Development Dialogue, 2, 75-91.

Salant, S. (1983): The vulnerability of price stabilization schemes to speculative attack, in: Journal of Political Economy, 91(1), 1-38.

Stigler, M., Prakash, A. (2013): The role of low stocks in generating volatility and panic, in: Prakash, A. (ed.), Safeguarding Food Security in Volatile Global Markets, 327-342, URL: http://www.fao. org/docrep/013/i2107e/i2107e.pdf.

Thirwall, A.P. (1979): The balance of payments constraint as an explanation of international growth rate differentials, in: BNL Quarterly Review, 32(128), 45-53.

Timmer, P. (1995): Getting agriculture moving: do markets send the right signals?, in: Food Policy, 20(5), 455-472.

Timmer, P. (2009): A world without agriculture: the structural transformation in historical perspective, Wendt Memorial Lecture, American Enterprise. 
Townsend, R. (1977): The eventual failure of price fixing schemes, in: Journal of Economic Theory, 14, 190-199.

UNCTAD (2006): UNCTAD: a brief historical overview, URL: http://unctad.org/en/Docs/ gds20061_en.pdf.

UNCTAD (2009): Trade and development report, Geneva: UNCTAD.

UNCTAD (2011): Commodities at a glance, March, URL: http://www.unctad.org/en/docs/ suc20112_en.pdf.

Ussher, L. (2009): Global imbalances and the key currency regime: the case for a commodity reserve currency, in: Review of Political Economy, 21(3), 403-421.

Ussher, L. (2011): Combining international monetary reform with commodity buffer stocks: Keynes, Graham and Kaldor, Working paper presented at the New Economic Thinking Conference, Bretton Woods, New Hampshire, 8-10 April.

Ussher, L., Haas, A., Töpfer, K., Jaeger, C.C. (2015): Keynes and the international monetary system: time for a tabular standard? Mimeo, doi: 10.13140/RG.2.1.1073.9043.

Williams, J., Wright, B. (1991): Storage and Commodity Markets, Cambridge, UK: Cambridge University Press.

World Bank (2007): World Development Report 2008: Agriculture for Development, Washington, DC, World Bank, URL: https://openknowledge.worldbank.org/handle/10986/5990 License: CC BY 3.0 IGO.

World Bank (2009): Global economic prospects 2009: commodities at the crossroads, URL: http:// issuu.com/world.bank.publications/docs/gep_2009/.

World Bank (2012): Using Public Food Grain Stocks to Enhance Food Security, Washington, DC: World Bank, URL: http://documents.worldbank.org/curated/en/2012/09/16687047/usingpublic-food-grain-stocks-enhance-food-security.

Wright, B. (2013): Addressing the biofuels problem: food security options for agricultural feedstocks, in: Prakash, A. (ed.), Safeguarding Food Security in Volatile Global Markets, 479-490, URL: http://www.fao.org/docrep/013/i2107e/i2107e.pdf.

Wright, B., Prakash, A. (2013): The fallacy of price interventions: a note on price bands and managed tariffs, in: Prakash, A. (ed), Safeguarding Food Security in Volatile Global Markets, 241-252, URL: http://www.fao.org/docrep/013/i2107e/i2107e.pdf.

Zanias, G.P. (2005): Testing for trends in the terms of trade between primary commodities and manufactured goods, in: Journal of Development Economics, 78(1), 49-59. 